p-ISSN: $2338-4794$

e-ISSN: 2579-7476

Vol.7. No. 3 September-Desember 2019

\title{
PENGARUH CORPORATE SOCIAL RESPONSIBILITY DAN CITRA PERUSAHAAN TERHADAP LOYALITAS PELANGGAN PT ABC PRESIDENT INDONESIA
}

\author{
Bongsu Saragih *) \\ *) Dosen Program Studi Manajemen FE UNKRIS \\ Alamat: Kampus UNKRIS, Jatiwaringin Jakarta Timur \\ Email: bongsu.saragih@gmail.com
}

\begin{abstract}
The purpose of this study was to determine the effect of corporate social responsibility and corporate image on customer loyalty in the company PT ABC President Indonesia. The research method used is quantitative research and explains each variable used. The population and sample in this study are customers who incidentally were taken when shopping for 100 respondents. The results of the research analysis say that corporate social responsibility and corporate image simultaneously have a positive effect on customer loyalty.
\end{abstract}

\section{Keywords: Corporate social responsibility, company image, customer loyalty}

\section{PENDAHULUAN}

Dalam menjalankan bisnisnya, perusahaan selalu perduli terhadap lingkungan. Kepedulian perusahaan dilakukan melalui program Tanggungjawab sosial perusahaan (Corporate Social Responsibility (CSR)). Program CSR perusahaan yang bernama Program Kemitraan dan Bina Lingkungan, terbagi menjadi 2 bagian yaitu: 1). Program Kemitraan. Bertujuan untuk mendorong kemajuan ekonomis suatu kawasan dengan menjadikan masyarakat di kawasan tersebut memiliki kemampuan produksi dan kemampulabaan, meningkatkan pola aktivitas kreatif dan produktif yang akhirnya mewujudkan tatanan masyarakat sejahtera dan mandiri. 2). Penyuluhan Program Kemitraan. Usaha Kecil adalah program untuk meningkatkan kompetensi usaha kecil agar menjadi tangguh dan mandiri melalui pemanfaatan dana dari bagian laba perusahaan. Penyuluhan Program Kemitraan adalah fasilitas untuk kebutuhan modal kerja atau investasi yang diberikan kepada calon Mitra Binaan.

Dalam dunia bisnis saat ini banyak perusahaan yang menerapkan program Corporate Social Responsibility (CSR) selain diwajibkan oleh pemerintah program ini juga dapat meningkatkan citra merek (brand image) atau citra perusahaan (corporate image). Hal ini dapat dilihat dalam kajian Wibisono (2017), menurutnya pada saat industrI berkembang setelah terjadi revolusi industri, kebanyakan masih memfokuskan dirinya sebagai organisasi yang mencari keuntungan belaka. Citra perusahaan akan membentuk sebuah reputasi. Sedangkan reputasi yang kuat dibangun dari tindakan operasional sehari-hari yang konsisten dengan tata nilai perusahaan. Diperlukan segmentasi dan penentuan skala prioritas untuk membidik kalayak yang secara kritis mempunyai dampak yang tinggi atau high impact (Susanto, 2017). Pembentukan citra perusahaan terdiri atas empat dimensi yaitu kualitas, 
kinerja, tanggung jawab dan daya tarik. Untuk kualitas, terdapat empat atribut yakni kualitas dari perusahaan dalam memberikan perhatian kepada konsumen, kualitas dari produk/jasa atau pelayanan yang diberikan, kepercayaan diri para stakeholder-nya serta atribut inovasi yang menggambarkan kemampuan perusahaan untuk terus menerus menghasilkan tingkat kualitas yang berkesinambungan. Kedua, dimensi kinerja yang mencerminkan sebagai perusahaan yang memiliki peluang untuk tumbuh dan berkembang serta perusahaan yang dikelola dengan baik, sedangkan dimensi ketiga adalah dimensi tanggung jawab yang memperlihatkan perusahaan yang peduli pada lingkungan dan memiliki tanggung jawab sosial. Adapun dimensi daya tarik, mencerminkan perusahaan sebagai tempat kerja idaman dan memiliki karyawan berkualitas (Dewi, 2017).

Penelitian ini bertujuan untuk menganalisis tentang pengaruh tanggung jawab sosial perusahaan dan citra perusahaan terhadap loyalitas pelanggan. Dilakukan pada perusahaan yang bergerak dibidang industri makanan dan minuman PT ABC Presiden Indonesia.

\section{LANDASAN TEORI}

\section{Loyalitas Pelanggan}

Mardalis (2015) mendefinisikan loyalitas sebagai kondisi dimana pelanggan mempunyai sikap positif terhadap suatu merek, mempunyai komitmen pada merek tersebut, dan bermaksud meneruskan pembeliannya di masa mendatang. Menurut kajian Oskamp dalam Dharmesta (2013) loyalitas berkembang mengikuti tiga tahap, yaitu kognitif, afektif, dan konatif. Biasanya pelanggan menjadi setia lebih dulu aspek kognitifnya, kemudian pada aspek afektif, dan akhirnya pada aspek konatif. Ketiga aspek tersebut biasanya sejalan, meskipun tidak semua kasus mengalami hal sama.

1. Tahap pertama: Loyalitas kognitif. Pelanggan yang mempunyai loyalitas tahap pertama ini menggunakan informasi keunggulan suatu produk atas produk lainnya. Loyalitas kognitif lebih didasarkan pada karakteristik fungsional, terutama biaya, manfaat dan kualitas. Pelanggan yang hanya mengaktifkan tahap kognitifnya dapat dihipotesiskan sebagai pelanggan yang paling rentan terhadap perpindahan karena adanya rangsangan pemasaran.

2. Tahap kedua: Loyalitas afektif. Sikap merupakan fungsi dari kognisi pada periode awal pembelian (masa sebelum konsumsi) dan merupakan fungsi dari sikap sebelumnya ditambah dengan kepuasan di periode berikutnya (masa setelah konsumsi). Munculnya loyalitas afektif ini didorong oleh faktor kepuasan yang menimbulkan kesukaan dan menjadikan objek sebagai preferensi. Kepuasan pelanggan berkolerasi tinggi dengan niat pembelian ulang di waktu mendatang. Pada loyalitas afektif, kerentanan pelanggan lebih banyak terfokus pada tiga faktor, yaitu ketidakpuasan dengan merek yang ada, persuasi dari pemasar maupun pelanggan merek lain, dan upaya mencoba produk lain.

3. Tahap ketiga: Loyalitas konatif. Konasi menunjukkan suatu niat atau komitmen untuk melakukan sesuatu. Niat merupakan fungsi dari niat sebelumnya (pada masa sebelum konsumsi) dan sikap pada masa setelah konsumsi. Maka loyalitas konatif merupakan suatu loyalitas yang mencakup komitmen mendalam untuk melakukan pembelian. Hasil penelitian Crosby dan Taylor dalam Dharmesta (2013) 
yang menggunakan model runtutan sikap: keyakinan-sikap-niat memperlihatkan komitmen untuk melakukan (niat) menyebabkan preferensi pemilih tetap stabil selama 3 tahun.

4. Tahap keempat: Loyalitas tindakan. Aspek konatif atau niat untuk melakukan berkembang menjadi perilaku dan tindakan. Niat yang diikuti oleh motivasi, merupakan kondisi yang mengarah pada kesiapan bertindak dan keinginan untuk mengatasi hambatan dalam melakukan tindakan tersebut. Jadi loyalitas itu dapat menjadi kenyataan melalui beberapa tahapan, yaitu pertama sebagai loyalitas kognitif, kemudian loyalitas afektif, dan loyalitas konatif, dan akhirnya sebagai loyalitas tindakan.

Faktor-faktor yang mempengaruhi loyalitas pelanggan menurut Zikmund dalam Vanessa (2017) adalah : a). Satisfaction (kepuasan). Kepuasan pelanggan merupakan perbandingan antara harapan sebelum melakukan pembelian dengan kinerja yang dirasakan. b). Emotional bonding (ikatan emosi). Dimana konsumen dapat terpengaruh oleh sebuah merek yang memiliki daya tarik tersendiri. Konsumen dapat diidentifikasikan dalam sebuah merek, karena sebuah merek dapat mencerminkan karakteristik konsumen tersebut. Ikatan yang tercipta dari sebuah merek ialah ketika konsumen merasa ikatan yang kuat dengan konsumen lain yang menggunakan produk atau jasa yang sama. c). Trust (kepercayaan). Kemauan seseorang untuk mempercayakan perusahaan atau sebuah merek untuk melakukan atau menjalankan sebuah fungsi. d). Choice reduction and habit (pengurangan pilihan dan kebiasaan). Jika konsumen akan merasa nyaman dengan sebuah merek, berikan mereka situasi kemudahan dalam bertransaksi. Bagian dari loyalitas konsumen, seperti pembelian produk secara teratur dapat didasari pada akumulasi pengalaman setiap saat. e). History with company (pengalaman dengan perusahaan). Sebuah pengalaman seseorang pada perusahaan dapat membentuk perilaku. Ketika konsumen mendapatkan pelayanan yang baik dari perusahaan, maka konsumen akan mengulangi perilaku pada perusahaan tersebut.

Indikator loyalitas pelanggan menurut Kotler dan Keller (2016) adalah: a). Kesetiaan. b). Ketahanan terhadap pengaruh negatif perusahaan. c). Mereferensikan secara total esistensi perusahaan. Pelanggan yang loyal tersebut dapat dilihat dari karakteristik yang dimiliki seperti yang diungkap oleh Griffin (2015) yang antara lain adalah: a). Melakukan pembelian secara teratur (makes regular repeat purchases). b). Membeli antarlini produk dan jasa (purchases across product and service mlines). c). Mereferensikan kepada orang lain (repers other). d). Menunjukkan kekebalan terhadap tarikan dari pesaing (demonstrates an immunity to the full of the competition).

Kesimpulan bahwa loyalitas pelanggan adalah kesetiaan para nasabahpelanggan yang dapat dilihat dalam transaksi mereka yang terus menerus terhadap produk atau jasa sepanjang waktu. Kemudian ditunjukkan dengan adanya perilaku yang positif seperti halnya merekomendasikan orang lain untuk membeli produk atau jasa kepada pelanggan yang loyal juga tidak dapat dengan mudah terpengaruh oleh tarikan dari para pesaing yang menawarkan produk atau jasa yang sedang dipasarkan. 


\section{Tanggungjawab Sosial Perusahaan atau Corporate Social Responsibility (CSR)}

Megnan dan Farrel dalam Susanto (2017) mendefinisikan CSR sebagai " $A$ business acts in socially responsible manner when its decision and account for and balance diserve stake holder interest". Definisi tersebut menekankan kepada perlunya memberikan perhatian secara seimbang terhadap kepentingan berbagai stakeholders yang beragam dalam setiap keputusan dan tindakan yang diambil oleh para pelaku bisnis melalui perilaku yang sosial/bertanggung jawab. Berbagai bentuk implementasi CSR dikemukakan oleh Ambadar (2017) dapat dijelaskan sebagai berikut: a). Konsumen, dalam bentuk penggunaan material yang ramah lingkungan, tidak berbahaya, serta memberikan informasi dan petunjuk yang jelas mengenai pemakaian yang benar atas produk-produk perusahaan. b). Karyawan, dalam bentuk persamaan hak dan kewajiban atas seluruh karyawan tanpa membedakan ras, suku, agama dan golongan. Karyawan mendapat penghargaan berdasarkan kompetensi dan hasil penilaian prestasinya. c). Komunitas dan lingkungan, dalam bentuk kegiatan kemanusiaan maupun lingkungan hidup, baik di lingkungan sekitar perusahaan maupun daerah lain yang membutuhkan. Kegiatan terhadap komunitas ini antara lain berupa kegiatan donor darah dengan melibatkan seluruh karyawan. d). Kesehatan dan keamanan, dalam bentuk penjagaan dan pemeliharaan secara rutin atas fasilitas dan lingkungan kantor sesuai petunjuk instasi yang terkait. Carol dalam Susanto (2017), menggambarkan CSR sebagai sebuah piramida, yang tersususn dari tanggung jawab ekonomi sebagai landasannya, kemudian tanggung jawab hukum, tantas tanggung jawab etika, dan tanggung jawab filantropis berada di puncak di piramida.

Susanto (2017), dengan lebih banyak memberikan perhatian kepada lingkungan sekitar, perusahaan dapat ikut berpartisipasi dalam usaha-usaha pelestarian lingkungan demi terpeliharanya kualitas kehidupan umat manusia dalam jangka panjang. Indikator tanggung jawab social perusahaan antara lain: a). Profit. Laba merupakan unsur yang paling penting dan menjadi tujuan utama dari setiap kegiatan usaha, karena hal itulah tak heran bila fokus utama dari sebuah perusahaan adalah meningkatkan profit atau mengejar harga saham setinggitingginya. Menurut Wibisono (2007), profit sendiri hakikatnya merupakan tambahan pendapatan yang digunakan untuk menjamin kelangsungan hidup perusahaan. Aktivitas yang ditempuh untuk mendongkrak profit antara lain dengan meningkatkan produktivitas dan melakukan efisiensi biaya, sehingga perusahaan memiliki keunggulan kompetitif yang dapat memberikan nilai tambah semaksimal mungkin. Wibisono (2017), peningkatan produktivitas bisa diperoleh dengan memperbaiki manajemen kerja melalui penyederhanaan proses, mengurangi aktivitas yang tidak efisien, menghemat waktu proses dan pelayanan. Termasuk juga menggunakan material sehemat mungkin dan memangkas biaya serendah mungkin. b). People. Masyarakat merupakan salah satu stakeholder yang penting dalam perusahaan. Karenanya, dukungan dari masyarakat sangat diperlukan bagi keberadaan, kelangsungan hidup, dan perkembangan perusahaan. Dengan alasan tersebut, Wibisono (2017), menjabarkan bahwa perusahaan perlu berkomitmen untuk berupaya memberikan manfaat sebesar-besarnya kepada masyarakat (people). c). Planet. Wibisono (2017) mendefinisikan 
lingkungan adalah sesuatu yang terkait dengan seluruh bidang kehidupan kita. Semua kegiatan yang dilakukan mulai bangun tidur di pagi hari hingga terlelap di malam hari berhubungan dengan lingkungan. Hubungan perusahaan dengan lingkungan adalah hubungan sebab akibat, dimana jika perusahaan merawat lingkungan, maka lingkungan akan memberikan manfaat bagi perusahaan.

\section{Citra Perusahaan}

Menurut Susanto (2017), citra perusahaan terbentuk dari asosiasi antara perusahaan dengan sekumpulan atribut positif maupun negatif. Misalnya perusahaan diasosiasikan dengan atribut-atribut: bermutu, layanan baik, tetapi kurang memiliki tanggung jawab sosial. Jadi sejatinya citra perusahaan berada dalam benak stakeholder-nya. Dari sisi individu, atribut-atribut yang menonjol inilah yang menentukan apakah sebuah perusahaan memiliki reputasi baik atau buruk. Citra akan terbentuk ketika manusia akan memproses stimuli yang akan ditangkap oleh indera (apersepsi) dan kemudian menafsirkannya (persepsi) dengan memberi arti melalui asosiasi berdasarkan pengetahuan yang dimiliki sebelumnya. Ketika pelanggan menangkap simbol perusahaan berupa logo, nama atau ucapan yang pelangan dengar, proses psikologis dalam diri pelanggan mengasosiasikan dengan atribut-atribut tertentu untuk memberi makna, sedangkan atribut diperoleh dari pengalaman sebelumnya yang terekam dalam ingatan (Susanto, 2017). Citra perusahaan memiliki fungsi penting sebagai hasil penciptakan kepercayaan. Citra, memiliki tiga faktor: desain perusahaan, komunikasi perusahaan dan perilaku perusahaan (Mustafa, 2011). Dapat dinyatakan bahwa ada empat poin yang termasuk citra perusahaan yaitu pikiran tentang perusahaan, pengetahuan dari perusahaan, prestise dan memiliki kemampuan dibandingkan dengan saingan (Mustafa, 2011)

Iman (2010), informasi yang lengkap mengenai citra perusahaan meliputi empat indikator sebagai berikut. a). Personality, keseluruhan karakteristik perusahaan yang dipahami publik sasaran seperti perusahaan yang dapat dipercaya, perusahaan yang mempunyai tanggung jawab sosial. b). Reputation, hal yang telah dilakukan perusahaan dan diyakini publik sasaran berdasarkan pengalaman sendiri maupun pihak lain seperti kinerja keamanan transaksi sebuah perusahaan. c). Value, Nilai-nilai yang dimiliki suatu perusahaan dengan kata lain budaya perusahaan seperti sikap manajemen yang peduli terhadap pelanggan, karyawan yang cepat tanggap terhadap permintaan maupun keluhan pelanggan. d). Corporate Identity, komponenkomponen yang mempermudah pengenalan publik sasaran terhadap perusahaan seperti logo, warna dan slogan. Menurut Macaulay dan Sarah (2016), tiga komponen yang mencerminkan image perusahaan, yaitu : a). Kualitas produk dan layanan yang dihasilkan. b). Cara memberikan pelayanan. c). Hubungan antar pribadi yang terbentuk melalui layanan tersebut.

\section{METODE PENELITIAN}

Penelitian ini, merupakan penelitian eksplanatory yang menjelaskan hubungan kausalitas setiap variabel penelitian, untuk mengetahui pengaruh setiap variabel bebas terhadap variabel terikat menggunakan analisis kuantitatif. Metode pengumpulan data yang digunakan dalam penelitian ini ialah dengan menggunakan data primer yang merupakan sumber data penelitian yang diperoleh secara langsung dari sumber asli (tidak melalui perantara). Data 
primer yang digunakan dalam penelitian ini adalah hasil pengisian kuesioner oleh responden, yaitu konsumen $\mathrm{PT} \mathrm{ABC}$ President Indonesia.

Populasi yang diteliti dalam penelitian ini adalah seluruh pelanggan PT ABC President Indonesia yang jumlahnya tidak diketahui. Dalam upaya mendapatkan ukuran sampel, dalam penelitian ini didasarkan pendapat Hair (2006) yang menyarankan ukuran sampel 5 sampai 10 untuk setiap indikator yang digunakan. Jumlah indikator pada penelitian ini adalah 10 indikator, maka jumlah sampel yang dapat diambil antara 50 sampel sampai dengan 100 sampel. Jumlah sampel maksimal yang ditentukan yaitu $10 \mathrm{x}$ $10=100$ responden. Teknik pengambilan sampel yang digunakan adalah metode accidental sampling. Metode analisis data yang digunakan dengan regresi linear berganda.

\section{HASIL ANALISIS DAN PEMBAHASAN}

\section{Hasil Analisis}

\section{Uji Validitas}

Validitas menunjukkan sejauh mana suatu pengukur itu mengukur apa yang ingin diukurnya. Suatu instrumen dapat dikatakan memiliki validitas yang tinggi apabila instrumen tersebut dapat menjalankan fungsi ukurnya, atau memberikan hasil ukur yang tepat dan akurat sesuai dengan maksud instrumen tersebut. Sisi lain yang penting adalah kecermatan pengukuran, yaitu kecermatan dalam mendeteksi perbedaan-perbedaan kecil yang ada pada item yang diukurnya. Pengukuran validitas pada instrumen ini dilakukan dengan korelasi pearson product moment antara skor butir dengan skor skalanya.

Validitas diukur dengan membandingkan nilai korelasi masingmasing indikator dengan nilai korelasi tabel ( $\mathrm{r}$ tabel). Nilai $\mathrm{r}$ tabel product moment pada $\mathrm{a}=0,05$ dan $\mathrm{n}=100$ sebesar 0,195. Dari pengolahan data terlihat dari 21 indikator yang diuji, semua indikator memiliki nilai koefisien korelasi positif dan lebih besar dari $r$ tabel, serta probabilitasnya lebih kecil dari a $=5 \%$, artinya ada hubungan yang signifikan antara skor masing-masing indikator dengan skor total. Korelasi yang signifikan menunjukkan bahwa indikator memang benar-benar dapat digunakan untuk mengukur variabel yang akan diukur, dengan kata lain instrumen yang digunakan valid dengan demikian dapat dipakai dalam penelitian.

\section{Reliabilitas}

Reliabilitas adalah indeks yang menunjukkan sejauh mana suatu alat ukur dapat dipercaya atau diandalkan. Menyusun suatu bentuk instrumen tidak hanya harus berisi pernyataan-pernyataan yang berdaya diskriminasi baik akan tetapi harus memiliki tingkat reliabilitas yang tinggi. Reliabel artinya tingkat keterpercayaan hasil suatu pengukuranpengukuran yang memiliki reliabilitas tinggi yaitu yang mampu memberikan hasil ukur yang terpercaya. Reliabilitas merupakan salah satu ciri atau karakter utama instrumen pengukuran yang baik. Pada penelitian ini digunakan reliabilitas dengan model Alpha Cronbach.

Tabel 1. Nilai Alpha Cronbach Masing-masing Variabel

\begin{tabular}{lcc}
\hline \multicolumn{1}{c}{ Variabel } & Alpha Cronbach & Keterangan \\
\hline Corporate social & 0,809 & Reliabel \\
responsibility & 0,787 & Reliabel \\
Citra perusahaan & 0,736 & Reliabel \\
Loyalitas pelanggan &
\end{tabular}


Pengujian reliabilitas instrumen dilakukan pada item pertanyaan yang sudah valid. Instrumen dinyatakan tidak reliabel jika nilai reliabilitas yang diperoleh tidak mencapai 0,6 (Nurgiyantoro, 2000). Hasil uji reliabilitas yang disajikan pada tabel 1 menunjukkan bahwa masing-masing nilai koefisien reliabilitas lebih besar dari 0,60 , sehingga instrumen yang digunakan dinyatakan reliabel.

\section{Analisis Regresi Linier Berganda}

Tabel 2. Rekapitulasi Hasil Analisis Regresi Linier Berganda

\begin{tabular}{lcccc}
\hline \multicolumn{1}{c}{ Variabel } & R Square & $\begin{array}{c}\text { Koefisien } \\
\text { Regresi }\end{array}$ & $\mathbf{t}$ & Sig \\
\hline $\begin{array}{l}\text { Konstanta } \\
\begin{array}{l}\text { Corporate social } \\
\text { responsibility }\end{array}\end{array} \quad 0.626$ & -0.852 & & \\
$\begin{array}{l}\text { Citra perusahaan } \\
\text { Pengujian Signifikansi }\end{array}$ & 0.658 & 4.704 & 0.000 \\
\hline F hitung $>$ F tabel $=81.321>3.09$ & 0.556 & 3.656 & 0.010 \\
\hline
\end{tabular}

Sumber : Data primer diolah 2019.

Dari hasil analisis regresi linier berganda table 2, dapat diketahui nilai koefisien determinasi ( $R$ square $)$ sebesar 0,626. Angka ini menunjukkan bahwa variabel corporate social responsibility $\left(\mathrm{X}_{1}\right)$ dan citra perusahaan $\left(\mathrm{X}_{2}\right)$ dapat menjelaskan variasi atau mampu memberikan kontribusi terhadap variabel loyalitas pelanggan (Y) sebesar $62,6 \%$, sedangkan sisanya sebesar $37,4 \%$ disebabkan oleh variabel lain yang tidak dimasukkan dalam penelitian

Hasil perhitungan regresi berganda tersebut dapat diketahui formulasinya sebagai berikut :

$$
Y=-0,852+0,658 X_{1}+0,556 X_{2}
$$$$
\text { Berdasarkan hasil persamaan }
$$
tersebut, dapat dijelaskan sebagai berikut : Koefisien regresi corporate social responsibility sebesar $0,658\left(b_{1}\right)$, menunjukkan besarnya pengaruh corporate social responsibility terhadap loyalitas pelanggan, koefisien regresi bertanda positif menunjukkan corporate social responsibility berpengaruh searah terhadap loyalitas pelanggan, yang berarti semakin baik corporate social responsibility akan menyebabkan peningkatan loyalitas pelanggan. Koefisien regresi citra perusahaan sebesar 0,556 $\left(b_{2}\right)$, menunjukkan besarnya pengaruh citra perusahaan terhadap loyalitas pelanggan, koefisien regresi bertanda positif menunjukkan citra perusahaan berpengaruh searah terhadap loyalitas pelanggan, yang berarti semakin baik citra perusahaan akan menyebabkan peningkatan loyalitas pelanggan.

\section{Pembahasan}

$\begin{array}{llr}\begin{array}{l}\text { Pengaruh } \\ \text { responsibility } \\ \text { Pelanggan }\end{array} & \begin{array}{l}\text { Corporate } \\ \text { terhadap }\end{array} & \begin{array}{r}\text { social } \\ \text { Loyalitas }\end{array} \\ & & \end{array}$

Dari hasil penelitian menunjukkan bahwa corporate social responsibility berpengaruh positif dan signifikan terhadap loyalitas pelanggan. Adapun indikator corporate social responsibility yang dapat meningkatkan loyalitas pelanggan adalah profit. Profit dicerminkan oleh PT ABC President Indonesia menjalankan perusahaan secara efektif. Sebagaimana pendapat Carol dalam Susanto (2007), tanggung 
jawab ekonomi adalah memperoleh laba, sebuah tanggung jawab agar dapat menghidupi karyawan, membayar pajak, dan kewajiban-kewajiban perusahaan lainnya.

\section{Pengaruh Citra Perusahaan terhadap Loyalitas Pelanggan}

Hasil penelitian menunjukkan bahwa citra perusahaan terbukti berpengaruh positif dan signifikan terhadap loyalitas pelanggan. Hal ini sesuai dengan pendapat Dewi (2007) bahwa citra positif perusahaan akan memberikan banyak manfaat bagi perusahaan, diantaranya adalah terciptanya sikap positif pelanggan terhadap perusahaan yang nantinya akan bermuara pada kepuasan dan kesetiaan pelanggan terhadap perusahaan. Indkator citra perusahaan yang dapat menciptakan loyalitas pelanggan yaitu corporate indentity yang dicerminkan dari logo PT $\mathrm{ABC}$ President Indonesia mudah dikenali pelanggan, warna logo $\mathrm{PT}$ ABC President Indonesia menarik, dan slogan PT ABC President Indonesia mudah diingat pelanggan.

\section{Pengaruh Corporate Social Responsibility dan Citra Perusahaan terhadap Loyalitas Pelanggan \\ Hasil penelitian menunjukkan} bahwa terbukti corporate social responsibility dan citra perusahaan berpengaruh positif terhadap loyalitas pelanggan.hal ini menunjukkan bahwa semakin baik penerapan corporate social responsibility dan citra perusahaan dapat meningkatkan loyalitas pelanggan. Hal ini sesuai konsep Griffin (2018) bahwa CSR adalah usaha untuk dapat menciptakan keseimbangan komitmennya terhadap kelompok maupun individu dalam lingkungan entitas bisnis tersebut yang meliputi konsumen, bisnis lain, karyawan dan investor. Citra PT ABC President Indonesia, dicerminkan dari personality, reputation, Value, dan corporate identity. Hal ini sesuai dengan konsep Alma (2011) bahwa citra didenifisikan sebagai kesan yang diperoleh sesuai dengan pengetahuan dan pengalaman seseorang tentang sesuatu.

\section{KESIMPULAN DAN SARAN}

\section{Kesimpulan}

Berdasarkan hasil penelitian dan pembahasan yang dilakukan maka dapat ditarik kesimpulan sebagai berikut : corporate social responsibility dan citra perusahaan secara simultan berpengaruh signifikan terhadap loyalitas pelanggan yang berarti bahwa semakin baik corporate social responsibility yang dilaksanakan oleh perusahaan dan didukung dengan citra perusahaan yang baik dapat meningkatkan loyalitas pelanggan.

\section{Saran}

1. PT ABC President Indonesia tetap melaksanakan corporate social corporate secara efektif, esifien dan fleksibel, sebagai sebuah wujud kepedulian perusahaan untuk mempertanggung jawabkan dampak operasinya dalam dimensi profit, people dan planet sosial, agar dampak tersebut menyumbang manfaat kepada masyarakat dan lingkungan sekitarnya.

2. Citra perusahaan dapat ditingkatkan dengan cara karyawan bersikap lebih ramah kepada pelanggan dan memberikan pelayanan sesuai yang dibutuhkan pelangan agar pelanggan menjadi loyal pada PT. ABC President Indonesia.

\section{DAFTAR PUSTAKA}

Alma, Buchari. 2011. Manajemen Pemasaran dan Pemasaran Jasa. Penerbit Alfabeta. Bandung. 
Ambadar, J. 2018. CSR dalam Praktik di Indonesia. PT Elex Media Komputindo. Jakarta:

Dewi, Kinorika. 2017. Corporate Social Responsibility dan Pengaruhnya pada Good Corporate Image. Jurnal Ekonomi Janavisi. 10 (36): 369383.

Dharmesta, B.S. 1999. Loyalitas Pelanggan : Sebuah Kajian, Konseptual Sebagai Panduan Bagi Peneliti. Jurnal Ekonomi dan Bisnis Indonesia. Vol. 14, No. 3: 73-88.

Griffin, Jill. 2015. Customer Loyalty: Menumbuhkan dan Mempertahankan Kesetiaan Pelanggan. Edisi revisi dan terbaru. Alih bahasa: Dwi Kartini Yahya.

Griffin, Jill. 2018. Costumer Loyalty How to Earn it, How to Keep it. Lexington Books: Singapore.

Hair Joseph, F, et al. 1998. Multivariate Data Analysis. New Jersey: Prentice Hall Published.

Iman, Mulyana dan Dwi Suwandi. 2010. Citra Perusahaan. Seri Manajemen Pemasara. www.e- iman.uni.cc.

Kotler, Philip dan Kevin Lane Keller. 2016. Marketing Management, $13^{\text {th }}$ Edition. New Jersey: Prentice-Hall

Macaulay, Steve dan Sarah Cook. 2016. Customer Service. PT. Gramedia Pusat Utama. Jakarta.

Mardalis, Ahmad. 2015. Meraih Loyalitas Pelanggan. Jurnal BENEFIT, Vol.9, No.2: 111-119.

Mustafa Karadeniz, 2009, The Importance Of Creating A Successful Corporate Identity and Corporate Image For Entreprises In Marketing Management, Journal of Naval Science and Engineering, Vol. 5,No.3: 1-15.

Nurgiantoro, Burhan, Gunawan, Marzuki. 2000. Statistik Terapan untuk Penelitian Ilmu-ilmu Sosial.
Penerbit Universitas Gajah Mada, Yogyakarta.

Susanto, A.B. 2017. Corporate Social Responsibility, A Strategic Managemen Approach. The Jakarta Consulting Grup Partner Ini Change. Jakarta.

Vanessa, Gaffar. 2017. Customer Relationship Management and Marketing Public Relations. Bandung: Alfabeta.

Wibisono, Yusuf. 2017. Membedah Konsep dan Aplikasi CSR. Gresik: Fascho Publishing.

Zikmund,Wiliam.G.et.al. 2003. Integrating Marketing Strategy and Information Technology. New Jersey: John Wiley and Sons. 